\title{
INCLUSÃO ESCOLAR: O QUE PERGUNTAM OS INTERESSADOS NA ÁREA?
}

\author{
Isabella Claro Tegon*, Maria Teresa Eglér Mantoan.
}

\section{Resumo}

Esse estudo surgiu do interesse de conhecer o teor do conteúdo de questões que foram formuladas por ouvintes de palestras sobre inclusão escolar proferidas em todo o Brasil por especialistas no assunto. Tais conteúdos foram analisados a partir do método qualiquantitativo Discurso do Sujeito Coletivo (DSC - LEFEVRE; LEFEVRE, 2012)1. A pesquisa revelou as indagações vindas de professores, pais e outros interessados na inclusão escolar, a tornar os resultados como um instrumento para o esclarecimento de questões relacionadas à efetivação da inclusão escolar.

\section{Palavras-chave: \\ Inclusão, Escola,Diferença.}

\section{Introdução}

A presente pesquisa agrupou questões que interessados em educação inclusiva levantaram sobre o tema ao fim de palestras. O levantamento das questões e suas categorias representam uma contribuição importante aos que se dedicam à implementação da Política Nacional de Educação Especial na Perspectiva da Educação Inclusiva (PNEEPEI) ${ }^{2}$ nas escolas comuns de ensino básico e superior. $O$ objetivo central foi evidenciar dúvidas que se repetiam voluntária e constantemente, como indiciado pelo estudo.

Foram analisadas e submetidas à técnica qualiquantitativa Discurso do Sujeito Coletivo 73 questões. O software DSCsoft $\AA$ auxiliou no agrupamento das questões, a categorizá-las. Comumente a técnica é utilizada para agrupar respostas, entretanto, aqui as respostas são novas perguntas que surgem após palestras, a criar discursos interrogativos.

\section{Resultados e Discussão}

571. Opiniões próprias. - A primeira opinião que nos ocorre, quando repentinamente somos indagados acerca de algo, não é geralmente nossa própria opinião, mas sim aquela corrente, de nossa casta, posição ou origem: é raro as opiniões próprias ficarem perto da superfície. (NIETZSCHE, 2017, p.249) ${ }^{3}$.

Os Discursos Coletivos, que se apresentam em primeira pessoa do singular e criados ao longo da pesquisa, revelam constante repetição das dúvidas, ao tornar explícitas representações sociais sobre o assunto. As categorias evidenciam anseios coletivos que devem ser mais bem compreendidos para que a efetivação da inclusão escolar seja cada vez mais assertiva de acordo com a legislação e os envolvidos na discussão.

O gráfico a seguir, pelas categorias, demonstra o sentido dado à inclusão pela interpretação da pesquisadora:

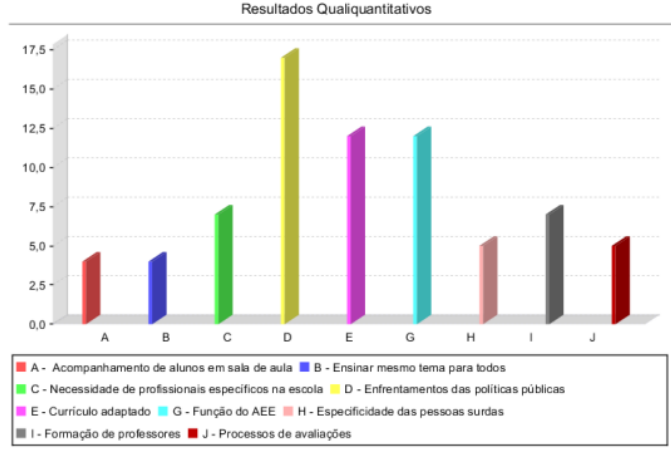

Gráfico 1: Resultados Qualiquantitativos. Produzido com auxílio do DSCsofte.

\section{Conclusões}

O estudo dos Discursos Coletivos revela que com as tendências da modernidade, firmaram-se, a partir do binarismo, identidades fixadas e opostas, a excluir os sujeitos considerados "não ideais". Essa perspectiva faz com que a questão de fundo da inclusão, a diferença de todos nós, ainda seja confundida com a diferença de alguns. A situação gera em professores, gestores, familiares, e outros interessados na área, dúvidas sobre a possibilidade de acesso, participação e permanência do público alvo da Educação Especial nas escolas comuns. A incerteza da eficácia da inclusão escolar é centrada, no geral, na incapacidade desses estudantes, e não nas estruturas escolares atuais, de caráter secularizado. Quando se diz sobre a ineficácia da escola, pensa-se também na falta de cumprimento das leis, tidas como asseguradoras dos direitos. Para além, deve-se considerar as disposições que envolvem o processo formativo dos professores pelos paradigmas modernos que minimizam potencialidades.

Revela-se que, com a democratização das escolas a grupos sociais antes excluídos, esses passaram a frequentar o ambiente escolar, mas seus conhecimentos, novos e ancorados pelos aparatos legais e educacionais voltados à inclusão, ainda são marginalizados. (MANTOAN, 2003, pp.17-18)4. Além da não valorização dos conhecimentos desses sujeitos, seus corpos apontam barreiras atitudinais, arquitetônicas, comunicacionais, sociais, antes não vistas nos ambientes escolares.

\section{Agradecimentos}

Agradeço ao $\mathrm{CNPq}$ e à Pró-Reitoria de Pesquisas da UNICAMP pelo apoio financeiro e institucional a partir da concessão da bolsa. À Faculdade de Educação pelos auxílios ímpares. À hospitalidade e orientação extraordinária da Prof. ${ }^{a}$ Dr. ${ }^{a}$ Maria Teresa E. Mantoan. Aos encontros com o Prof. Dr. Fernando Lefèvre. A toda troca intelectual e emocional da amiga e companheira de jornada acadêmica, Julia Smidt de Oliveira. A família e amigas, por assegurarem meus anseios.

\footnotetext{
1 LEFEVRE, Fernando; LEFEVRE, Ana Maria Cavalcanti. Pesquisa de Representação Social. Um enfoque qualiquantitativo. Brasília, DF: Liberlivro, 2012. 2 BRASIL. Ministério da Educação. Política Nacional de Educação Especial na perspectiva da Educação Inclusiva. Brasília: MEC/SEESP, 2008

${ }^{3}$ NIETZSCHE, F. W.; SOUZA, P. C. de. Humano, demasiado humano: um livro para espíritos livre. [s.1.] : São Paulo, SP: Companhia de Bolso, 2017., 2017.

${ }^{4}$ MANTOAN, Maria Teresa Eglér. Inclusão escolar: O que é? Por quê? Como fazer? (Coleção cotidiano escolar) São Paulo, SP: Moderna, 2003.
} 